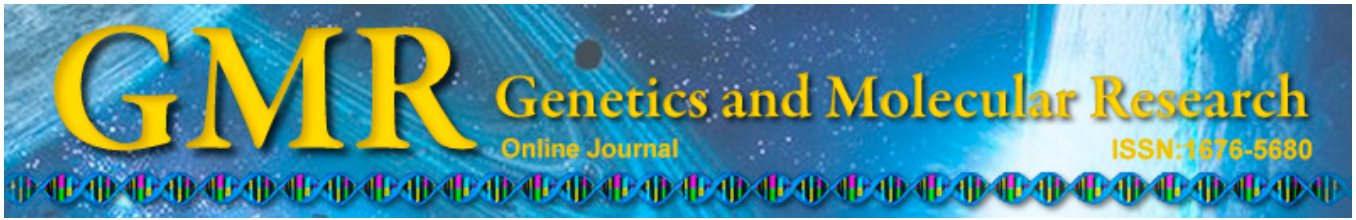

\title{
Molecular typing of Salmonella from Sergipe, Northeastern Brazil, showing the epidemiological relationship between poultry and human infection
}

\author{
P.B.P. Góis, M.R.P. Carneiro, S. Jain, M.I.S. Santos, M.V.A. Batista and \\ A.L. Cândido \\ Departamento de Morfologia, Universidade Federal de Sergipe, \\ São Cristóvão, SE, Brasil \\ Corresponding author: A.L. Cândido \\ E-mail: virologiacomparada@hotmail.com
}

Genet. Mol. Res. 14 (3): 11389-11395 (2015)

Received February 1, 2015

Accepted June 26, 2015

Published September 25, 2015

DOI http://dx.doi.org/10.4238/2015.September.25.6

\begin{abstract}
Randomly amplified polymorphic DNA (RAPD) has been widely used for epidemiological and phylogenetic purposes owing to its rapidity and efficiency. The aim of this study was to perform genome typing of Salmonella samples isolated from different sources by RAPD profiling. Thirty-three Salmonella samples from the bacterial collection of the Laboratório de Virologia Comparada, Departamento de Morfologia, Universidade Federal de Sergipe, Brazil, and two standard samples were used. RAPD profiling was conducted using six primers of the Ready-To-Go RAPD system. The amplified products were electrophoresed on 5\% polyacrylamide gel and silver-stained. RAPD analysis resulted in reproducible and stable banding patterns and showed high genetic diversity among the isolated strains. The Primer P1-generated dendrogram showed an epidemiologic relationship between the human
\end{abstract}


and poultry isolated samples, highlighting the usefulness of RAPD for molecular typing and epidemiological studies.

Key words: Salmonella; Randomly amplified polymorphic DNA; Randomly amplified polymorphic DNA; Epidemiology; Molecular typing

\section{INTRODUCTION}

Members of the genus Salmonella, of the family Enterobacteriaceae, are important foodborne pathogens. They are among the most important causes of enteric pathologies in the world, and are therefore relevant to public health owing to their high rates of endemicity and morbidity (Chansiripornchai et al., 2000; Ruiz et al., 2003).

The Salmonella genome is characterized by the presence of a large number of genetic elements (Salmonella pathogenicity islands) that can be acquired by horizontal transmission. These pathogenicity islands allow bacteria to rapidly gain complex virulence and enable the emergence of new antibiotic-resistant epidemic strains (Yan et al. 2004), resulting in great genetic diversity.

With the advent of molecular biology, many DNA-based methods have emerged that allow for the detection of genetic variations present in isolated samples, as well as inter- and intra-serotype differentiation (Lin et al., 1996; Soto et al., 1999; Nath et al., 2010). Molecular typing of Salmonella is very important in epidemiological studies because it reflects the genetic link between samples, which can be used to identify the sources of microorganisms, trace the transmission and environment diffusion chain, and monitor the tendency to antimicrobial resistance. Use of these modern molecular typing methods could thus lead to the establishment of more efficient public health policies, permitting better sanitary control of the products offered to the population, and could even serve as a complement to the conventional techniques used for biotyping (Laconcha et al., 1998; De Cesare et al., 2001).

Randomly amplified polymorphic DNA (RAPD), also known as arbitrarily primedpolymerase chain reaction (PCR), amplifies DNA fragments through random primers. It does not require any previous knowledge of the DNA sequence of the target organisms, and results in simpler, low-cost, and rapid detection of the genetic variations present in isolated samples (Colauto et al., 2002; Ruiz et al., 2003; Santos and Bäumler, 2004). RAPD has been used as a tool to trace Salmonella epidemiologically, to distinguish Salmonella strains from different geographical origins, and for complementing serotyping and phage typing methods (Soto et al., 1999; De Cesare et al., 2001; Quintaes et al., 2002; Lim et al., 2005; Smith et al., 2011; Rezk et al., 2012).

The aim of the present study was to assess the inter- and intra-serotype diversity of Salmonella spp and verify a possible epidemiologic relationship using the RAPD technique.

\section{MATERIAL AND METHODS}

\section{Bacterial strains}

Thirty-three Salmonella spp strains isolated from different sources (poultry, oysters, environmental water, human feces, and human blood, Table 1) from the state of Sergipe, Northeastern Brazil, were utilized in this study. These epidemiologically unrelated sporadic 
isolates belonged to ten different serotypes: nine Salmonella enterica serotype Agona; three $S$. enterica subsp enterica (8,20:Z4,Z23:-); one S. enterica subsp enterica (068:Z4,Z23:-); nine $S$. Enteritidis; two $S$. Houtenae; one $S$. Newport; three $S$. Panama; two $S$. Schwarzengrund; one $S$. Tennessee; and two $S$. Typhimurium. Two international standard strains, ATCC 13076 and ATCC 13311, were also included.

Table 1. Randomly amplified polymorphic DNA (RAPD) profile of Salmonella spp samples isolated from different sources in the state of Sergipe, Brazil.

\begin{tabular}{|c|c|c|c|c|c|c|c|c|}
\hline No. of type & Serotype & Source & Primer P1 & Primer P2 & Primer P3 & Primer P4 & Primer P5 & Primer P6 \\
\hline 7 & $S$. Enteritidis & ATCC 13076 & A1 & B1 & $\mathrm{C} 1$ & D1 & E1 & $\mathrm{F} 1$ \\
\hline 5 & $S$. Enteritidis & Human feces & A1 & B2 & $\mathrm{C} 2$ & D2 & E2 & F2 \\
\hline 9 & $S$. Enteritidis & Human feces & A2 & B3 & $\mathrm{C} 3$ & D3 & E3 & F3 \\
\hline 11 & S. Enteritidis & Human feces & A3 & B4 & $\mathrm{C} 4$ & D4 & E3 & F4 \\
\hline 12 & $S$. Enteritidis & Human feces & $\mathrm{A} 3$ & B3 & $\mathrm{C} 3$ & D1 & $\mathrm{E} 4$ & F3 \\
\hline 17 & $S$. Enteritidis & Human feces & A2 & B5 & $\mathrm{C} 5$ & D5 & E5 & F5 \\
\hline 31 & $S$. Enteritidis & Human feces & A4 & B6 & $\mathrm{C} 6$ & D6 & E6 & F6 \\
\hline 32 & $S$. Enteritidis & Human feces & A5 & B7 & $\mathrm{C} 7$ & D7 & E7 & F7 \\
\hline 37 & $S$. Enteritidis & Human blood & A6 & B8 & $\mathrm{C} 8$ & D7 & E8 & F8 \\
\hline 18 & $S$. Enteritidis & Poultry & A7 & B9 & $\mathrm{C} 8$ & D1 & E9 & F3 \\
\hline 24 & S. Agona & Poultry & A8 & $\mathrm{B} 10$ & C9 & D8 & E10 & F9 \\
\hline 25 & S. Agona & Poultry & A9 & B11 & $\mathrm{C} 10$ & D9 & E11 & F9 \\
\hline 26 & $S$. Agona & Poultry & A10 & B11 & $\mathrm{C} 10$ & D10 & E12 & F9 \\
\hline 27 & $S$. Agona & Poultry & A11 & $\mathrm{B} 12$ & $\mathrm{C} 10$ & D11 & E13 & F10 \\
\hline 28 & $S$. Agona & Poultry & $\mathrm{A} 12$ & $\mathrm{~B} 13$ & $\mathrm{C} 10$ & D12 & E13 & F11 \\
\hline 4 & S. Agona & Env. water: & A13 & B14 & $\mathrm{C} 11$ & D13 & E14 & F12 \\
\hline 6 & S. Agona & Env. water: & A14 & $\mathrm{B} 15$ & $\mathrm{C} 12$ & D14 & E15 & F13 \\
\hline 8 & $S$. Agona & Env. water: & A15 & B16 & $\mathrm{C} 13$ & D15 & E16 & F14 \\
\hline 22 & $S$. Agona & Env. water: & A16 & B17 & $\mathrm{C} 14$ & D16 & E17 & F15 \\
\hline 10 & $S$. Typhimurium & ATCC 13311 & A17 & $\mathrm{B} 18$ & $\mathrm{C} 15$ & D17 & E18 & F16 \\
\hline 16 & $S$. Typhimurium & Human blood & A18 & B19 & $\mathrm{C} 16$ & D17 & E19 & F17 \\
\hline 36 & $S$. Typhimurium & Human blood & A19 & B20 & $\mathrm{C} 17$ & D18 & E20 & F18 \\
\hline 34 & S. enterica subsp enterica* & Human blood & A6 & $\mathrm{B} 21$ & $\mathrm{C} 18$ & D19 & $\mathrm{E} 21$ & F19 \\
\hline 35 & S. enterica subsp enterica* & Human blood & $\mathrm{A} 20$ & $\mathrm{~B} 22$ & $\mathrm{C} 19$ & $\mathrm{D} 20$ & E22 & F19 \\
\hline 19 & S. enterica subsp enterica* & Poultry & A7 & B23 & $\mathrm{C} 20$ & D21 & E23 & F20 \\
\hline 23 & S. enterica subsp enterica $\dagger$ & Poultry & A6 & B22 & $\mathrm{C} 21$ & D22 & E24 & F19 \\
\hline 33 & $S$. Panama & Poultry & $\mathrm{A} 21$ & B24 & $\mathrm{C} 10$ & D7 & $\mathrm{E} 25$ & $\mathrm{~F} 21$ \\
\hline 20 & S. Panama & Env. water: & $\mathrm{A} 21$ & B25 & $\mathrm{C} 18$ & D23 & E26 & $\mathrm{F} 21$ \\
\hline 21 & S. Panama & Env. water: & A22 & B26 & $\mathrm{C} 18$ & D24 & E27 & F21 \\
\hline 29 & S. Schwarzengrund & Poultry & A23 & B27 & $\mathrm{C} 22$ & D25 & E28 & F22 \\
\hline 30 & S. Schwarzengrund & Poultry & $\mathrm{A} 23$ & B28 & $\mathrm{C} 23$ & D25 & E28 & $\mathrm{F} 22$ \\
\hline 2 & $S$. Houtenae & Env. water: & A24 & B29 & $\mathrm{C} 24$ & D26 & E29 & F23 \\
\hline 3 & $S$. Houtenae & Env. water: & A24 & B30 & $\mathrm{C} 11$ & D26 & E29 & F12 \\
\hline 13 & $S$. Newport & Human feces & A25 & B31 & $\mathrm{C} 25$ & D27 & E30 & $\mathrm{F} 24$ \\
\hline 1 & $S$. Tennessee & Oysters & A26 & B32 & $\mathrm{C} 26$ & D28 & E31 & F25 \\
\hline
\end{tabular}

A1-A26, B1-B32, C1-C26, D1-D28, E1-E31, F1-F25 represent the different RAPD profiles relating to each primer *S. enterica subsp enterica (8,20:64,Z23:-); ${ }^{\dagger}$ S. enterica subsp. enterica (068:64,Z23:-); ${ }^{\star}$ Environmental water.

\section{DNA extraction}

DNA extraction was carried out according to Sambrook et al. (2001). Samples were grown in $1 \mathrm{~L}$ of Luria-Bertani broth, at $37^{\circ} \mathrm{C}$ with agitation $(120 \mathrm{rpm})$ for $12 \mathrm{~h}$ and then centrifuged at $5000 \mathrm{~g}$ for $20 \mathrm{~min}$ at $4^{\circ} \mathrm{C}$. Pellets were resuspended in phosphate-buffered saline (PBS, pH 7.2). To extract total DNA, bacterial suspensions in PBS were centrifuged at 8000

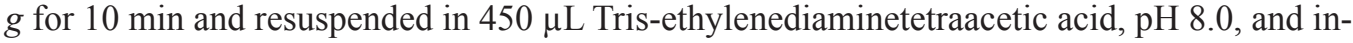
cubated at $56^{\circ} \mathrm{C}$ for $3 \mathrm{~h}$ together with $20 \mu \mathrm{L} 20 \mathrm{mg} / \mathrm{mL}$ Proteinase $\mathrm{K}, 2 \mu \mathrm{L} 10 \mathrm{mg} / \mathrm{mL}$ RNAse, and $30 \mu \mathrm{L} 10 \%$ sodium dodecyl sulfate. They were then inactivated at $70^{\circ} \mathrm{C}$ for $10 \mathrm{~min}$ and 
centrifuged at $3000 \mathrm{~g}$ for $5 \mathrm{~min}$. The supernatant was transferred to a new tube and extracted with 1:1 phenol:chloroform four times at $3000 \mathrm{~g}$ for $15 \mathrm{~min}$. Later, the samples were precipitated with $95 \%$ ethanol after addition of $1 / 10(\mathrm{v} / \mathrm{v})$ potassium acetate. Samples were then left at $-20^{\circ} \mathrm{C}$ for $20 \mathrm{~min}$ and centrifuged at $11,000 \mathrm{~g}$ for $20 \mathrm{~min}$. The DNA pellet was dried at room temperature and resuspended in $50 \mu \mathrm{L}$ ultra-pure water.

\section{RAPD}

Six Ready-To-Go system (Amersham Biosciences, NJ, USA) primers were used to carry out the RAPD-PCR: P1 (5'-GGTGCGGGAA-3'), P2 (5'-GTTTCGCTCC-3'), P3 (5'-GTAGACCCGT-3'), P4 (5'-AAGAGCCCGT-3'), P5 (5'-AACGCGCAAC-3'), and P6 (5'-CCCGTCAGCA-3'). The mix consisted of $2.5 \mu \mathrm{L}$ PCR buffer $(30 \mathrm{mM} \mathrm{KCl}$ and $10 \mathrm{mM}$ Tris- $\mathrm{HCl}, \mathrm{pH} 8.3), 0.75 \mu \mathrm{L} \mathrm{MgCl}_{2}(3 \mathrm{mM}), 16.9 \mu \mathrm{L}$ diethylpyrocarbonate-treated water, $3 \mu \mathrm{L}$ primer (15 pmol), $0.6 \mu \mathrm{L}$ dNTPs $(0.4 \mathrm{mM}), 0.25 \mu \mathrm{L}$ Taq DNA polymerase $(0.25 \mathrm{U})$, and $1 \mu \mathrm{L}$ DNA. Tubes were heated at $95^{\circ} \mathrm{C}$ in a thermo cycle (Thermo Hybaid PCR Sprint) for 5 min, before the addition of $0.25 \mu \mathrm{L}$ Taq DNA polymerase, followed by 40 cycles at $94^{\circ} \mathrm{C}$ for 30 $\mathrm{s}, 35^{\circ} \mathrm{C}$ for $1 \mathrm{~min}$, and $72^{\circ} \mathrm{C}$ for $2 \mathrm{~min}$. After 40 cycles, a final extension at $72^{\circ} \mathrm{C}$ was carried out for $5 \mathrm{~min}$. The amplified products were separated by electrophoresis on a $5 \%$ polyacrylamide gel at $112 \mathrm{~V}$ for $3 \mathrm{~h}$ and visualized according to the PlusOne DNA Silver Staining Kit ${ }^{\mathrm{TM}}$ (Amersham Biosciences). PCR and gel electrophoresis were repeated at least three times in independent experiments to verify the reproducibility of the results. Optimization of the amplification conditions for PCR was carried out by varying the amounts of primer (3-5 $\mu \mathrm{L})$ and the annealing temperatures $\left(35-40^{\circ} \mathrm{C}\right)$, using the references Escherichia coli BL21, C1a, ATCC 13 076, and ATCC 13311.

\section{Data analysis}

The RAPD patterns of individual strains were scored as discrete variables in a binary manner based on band presence or absence: 1 was used to indicate presence and 0 to indicate absence of a band in the profile. Diversity and genetic relationship among the strains were obtained using unweighted pair-group method with arithmetic average (UPGMA) and the NTSYS-pc 1.7 program (Rohlf, 1992). The discrimination index was calculated using Simpson's index of diversity (Hunter and Gaston, 1988).

\section{RESULTS AND DISCUSSION}

PCR-based fingerprinting using RAPD has been used widely for genome identification, and the RAPD technique using up to six primers has been reported to be a good tool for molecular typing, permitting the execution of public health measures necessary to control infection (Chansiripornchai et al., 2000; De Cesare et al., 2001; Khoodoo et al., 2002; Quintaes et al., 2002). During this study, we found that the best amplification conditions for RAPD-PCR were an annealing temperature of $35^{\circ} \mathrm{C}$ with $3 \mu \mathrm{L}$ primer. No loss in band numbers or shift in the position of PCR bands was observed in the reproducibility tests. Also, no PCR products were observed in reactions performed in the absence of primer or in the absence of DNA template.

The six primers utilized in this study showed different discriminatory powers, producing a variety of PCR profiles (Table 1). It was possible to discriminate all 35 samples of 
Salmonella, showing that they were all genetically different. No primer alone was able to discriminate all isolates. However, the use of any two primers was enough to differentiate all 35 samples (Table 2). The samples that showed at least one polymorphic band were considered sufficiently divergent. Primer P2 produced the maximum number of RAPD profiles and thus has better discriminatory power than the others. The six RAPD-PCR 10-mer primers generated a total of 178 distinct RAPD profiles (Table 1), and proved to be useful for differentiating all the isolated samples, as mentioned above.

Table 2. Discrimination indices for different primers.

\begin{tabular}{lcc}
\hline Primer & No. of types & Discrimination index \\
\hline RAPD analysis P1 & 26 & 0.983 \\
RAPD analysis P2 & 32 & 0.995 \\
RAPD analysis P3 & 26 & 0.973 \\
RAPD analysis P4 & 28 & 0.985 \\
RAPD analysis P5 & 31 & 0.993 \\
RAPD analysis P6 & 25 & 0.977 \\
\hline
\end{tabular}

RAPD $=$ randomly amplified polymorphic DNA.

Using these primers, a good Simpson's index of discrimination was obtained for Salmonella isolates. These high index values indicate the potential ability of the technique to differentiate between different isolates (Table 2). The discriminatory power is determined by the number of types defined and their relative frequencies. Thus, despite the fact that both primers $\mathrm{P} 1$ and $\mathrm{P} 3$ can differentiate 26 types, $\mathrm{P} 1$ is more discriminatory than P3 (Table 2). The above results show the presence of a great genetic diversity within the samples found in the state of Sergipe, Brazil. Such diversity may determine new genetic combinations, consequently improving virulence factors and resistant genes present in different samples.

Seven different RAPD profiles from 10 samples of $S$. Enteritidis were obtained with primer P1 (Table 1). Samples 5 and 7, samples 9 and 17, and samples 11 and 12 showed identical profiles (Table 1), all from human feces. Samples 18, 31, 32, and 37 produced individual profiles. Similarly, samples 37 (S. Enteritidis) and 34 [S. enterica subsp enterica (8,20:64,Z23:-)], both isolated from human blood, presented the same profile as sample 23 [S. enterica subsp enterica (068:64,Z23:-)], isolated from poultry; moreover, sample 19 [S. enterica subsp enterica (8,20:64,Z23:-)] was identical to sample 18 (S. Enteritidis).

A dendrogram using the RAPD results produced by primer P1 grouped together Enteritidis and enterica isolated from human blood, human feces, and poultry, showing a possible epidemiological relationship between these samples (Figure 1). The samples isolated from human feces and human blood were collected from patients showing diarrhea and septicemia symptoms. The poultry for sample isolation were obtained from a street market, probably with unhygienic conditions. The grouping of these samples close together indicates that the infection in humans probably began with ingestion of the contaminated poultry. Poultry are an important source of protein in the Brazilian diet and are often bought in open street markets. The results of this study reinforce the need for better sanitary control measures for this product.

As the RAPD technique is simple, rapid, and rather cheap, we suggest that it can serve as an additional tool for studying the genetic diversity and molecular epidemiology of Salmonella species, both inter- and intra-serovars. The isolation of various serovars of Salmonella from different sources indicates the presence and the wide distribution of Salmonella in the 
state of Sergipe, Northeastern Brazil. Knowledge of genetic variability of subtypes of different serovars and the sources of Salmonella may provide valuable additional information for research, risk management, and public health strategies.

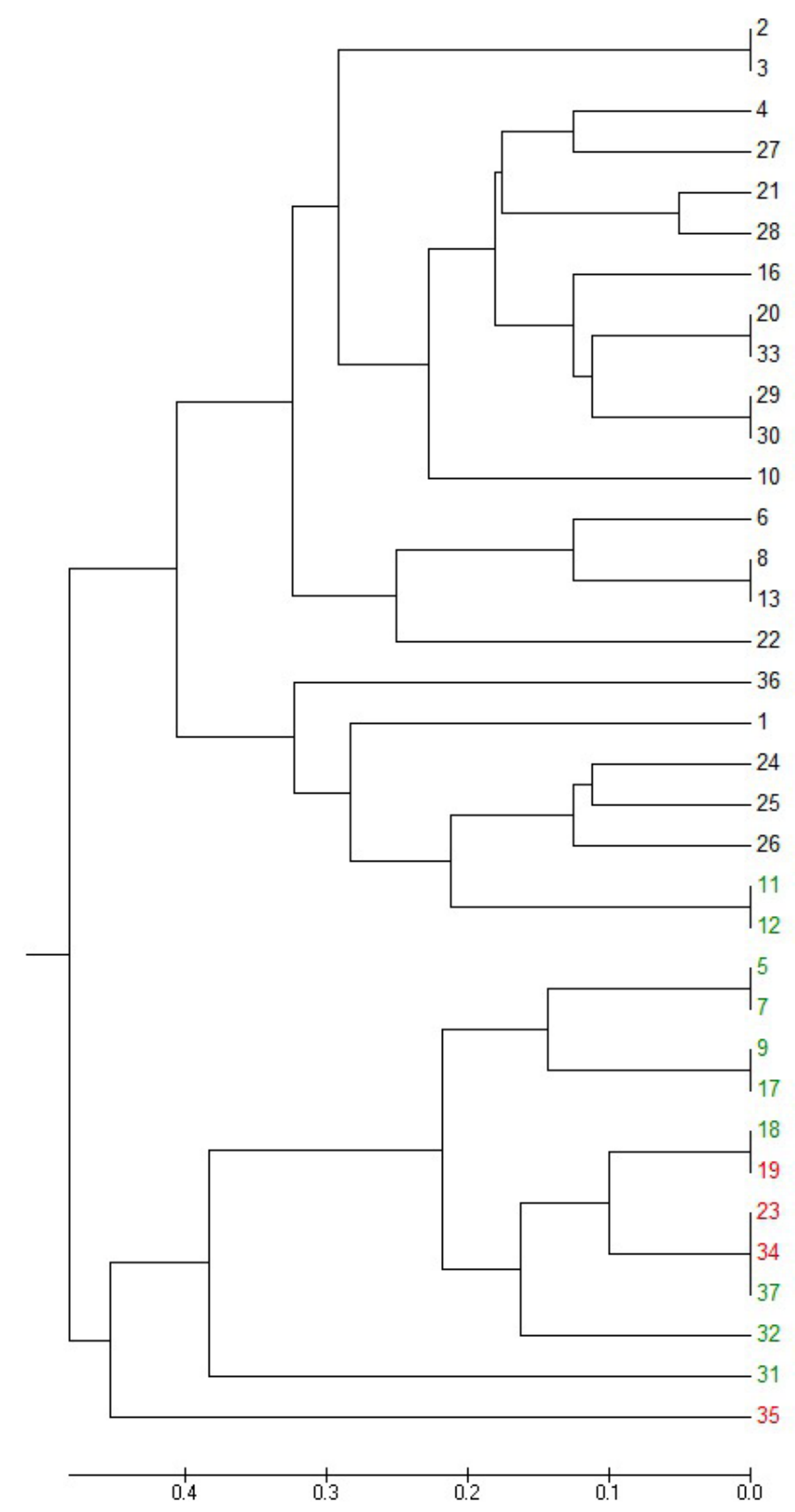

Figure 1. Dendrogram of randomly amplified polymorphic DNA (RAPD) profiles using primer P1. Salmonella Enteritidis and S. enterica isolates are marked in green and red, respectively. 


\section{Conflicts of interest}

The authors declare no conflict of interest.

\section{ACKNOWLEDGMENTS}

We would like to thank Edmar Ramos de Siqueira (EMBRAPA-SE) for laboratorial support and Dalia dos Prazeres Rodrigues (FIOCRUZ-RJ) for serotyping the samples. Research supported by Fundação de Amparo à Pesquisa do Estado de Sergipe (FAPESE), Fundação de Apoio à Pesquisa e à Inovação Tecnológica do Estado de Sergipe (FAPITEC- SE), Coordenação de Aperfeiçoamento de Pessoal de Nível Superior (CAPES), and Conselho Nacional de Desenvolvimento Científico e Tecnológico (CNPq).

\section{REFERENCES}

Chansiripornchai N, Ramasoota P, Bangtrakulnonth A, Sasipreeyajan J, et al. (2000). Application of randomly amplified polymorphic DNA (RAPD) analysis for typing avian Salmonella enterica subsp. enterica. FEMS. Immunol. Med. Microbiol. 29: 221-225.

Colauto NB, Dias ES, Gimenes MA and Eira AF (2002). Genetic characterization of isolates of the basidiomycete Agaricus blazei by RAPD. Braz. J. Microbiol. 33: 131-133.

De Cesare A, Manfreda G, Dambaugh TR, Guerzoni ME, et al. (2001). Automated ribotyping and random amplified polymorphic DNA analysis for molecular typing of Salmonella Enteritidis and Salmonella Typhimurium strains isolated in Italy. J. Appl. Microbiol. 91: 780-785.

Hunter PR and Gaston MA (1988). Numerical index of the discriminatory ability of typing systems: an application of Simpson's index of diversity. J. Clin. Microbiol. 26: 2465-2466.

Khoodoo MH, Issack MI and Jaufeerally-Fakim Y (2002). Serotyping and RAPD profiles of Salmonella enterica isolates from Mauritius. Lett. Appl. Microbiol. 35: 146-152.

Laconcha I, López-Molina N, Rementeria A, Audicana A, et al. (1998). Phage typing combined with pulsed-field gel electrophoresis and random amplified polymorphic DNA increases discrimination in the epidemiological analysis of Salmonella Enteritidis strains. Int. J. Food. Microbiol. 40: 27-34.

Lim H, Lee KH, Hong CH, Bahk GJ, et al. (2005). Comparison of four molecular typing methods for the differentiation of Salmonella spp. Int. J. Food. Microbiol. 105: 411-418.

Lin AW, Usera MA, Barrett TJ and Goldsby RA (1996). Application of random amplified polymorphic DNA analysis to differentiate strains of Salmonella Enteritidis. J. Clin. Microbiol. 34: 870-876.

Nath G, Maurya P and Gulati AK (2010). ERIC PCR and RAPD based fingerprinting of Salmonella Typhi strains isolated over a period of two decades. Infect. Genet. Evol. 10: 530-536.

Quintaes BR, Leal NC, Reis EM, Fonseca EL, et al. (2002). Conventional and molecular typing of Salmonella Typhi strains from Brazil. Rev. Inst. Med. Trop. Sao Paulo 44: 315-319.

Rezk NA, Mansour H, Ghoneim NH and Rifaat MM (2012). Typing of Salmonella Typhi strains isolated from Egypt by RAPD PCR. 3 Biotech. 2: 17-25.

Rohlf FJ (1992). NTSYS-PC version 1.7 numerical taxonomy and multivariate analysis system. Exeter Software Publisher, New York.

Ruiz M, Rodríguez JC, Sirvent E, Escribano I, et al. (2003). Usefulness of different techniques in the study of the epidemiology of salmonellosis. APMIS. 111: 848-856.

Sambrook J, Fritsch EF and Maniatis T (2001). Molecular cloning: a laboratory manual. 2nd edn. Cold Spring Harbor, New York.

Santos RL and Bäumler AJ (2004). Cell tropism of Salmonella enterica. Int. J. Med. Microbiol. 294: 225-233.

Smith SI, Fowora MA, Goodluck HA, Nwaokorie FO, et al. (2011). Molecular typing of Salmonella spp isolated from food handlers and animals in Nigeria. Int. J. Mol. Epidemiol. Genet. 2: 73-77.

Soto SM, Guerra B, González-Hevia MA and Mendoza MC (1999). Potential of three-Way randomly amplified polymorphic DNA analysis as a typing method for twelve Salmonella serotypes. Appl. Env. Microbiol. 65: 4830-4836.

Yan SS, Pendrak ML, Abela-Ridder B, Punderson JW, et al. (2004). An overview of Salmonella typing - Public health perspectives. Clin. Appl. Immunol. Reviews. 4: 189-204. 